\title{
Studies on Genetic Variability, Heritability and Genetic Advance in Fenugreek (Trigonella foenum-graecum L.)
}

\author{
Jyothi Veerayya Hosamath $^{{ }^{*}}$, R.V. Hegde ${ }^{1}$, C.K. Venugopal ${ }^{1}$, \\ A.G. Vijayakumar ${ }^{2}$ and M.G. Hegde ${ }^{3}$ \\ ${ }^{1}$ Department of Horticulture, College of Agriculture, University of Agricultural Sciences, \\ Dharwad - 580 005, Karnataka, India \\ ${ }^{2}$ Regional Agriculture Research Station, Vijayapur, Karnataka, India \\ ${ }^{3}$ Department of Agricultural Entomology, College of Agriculture, Dharwad, Karnataka, India \\ *Corresponding author
}

\begin{tabular}{|c|c|}
\hline & A B S T R A C T \\
\hline & \multirow{8}{*}{$\begin{array}{l}\text { Thirty five germplasm of fenugreek (Trigonella foenum-graecum L.) along with check } \\
\text { were evaluated at University of Agricultural Sciences, Dharwad. High genotypic } \\
\text { coefficient of variability and phenotypic coefficient of variability coupled with high } \\
\text { heritability coupled with genetic advance as per cent mean were observed for the } \\
\text { characters plant height ( } 30 \text { and } 60 \text { DAS), number of branches per plant ( } 60 \text { and } 90 \text { DAS), } \\
\text { number of leaves ( } 30,60 \text { and } 90 \text { DAS), number of pods per plant and hundred seed weight. } \\
\text { High heritability coupled with the high genetic advance as per cent mean were noted for } \\
\text { plant height ( } 30 \text { and } 60 \text { DAS), number of branches ( } 60 \text { and } 90 \text { DAS), number of leaves } \\
\text { ( } 30,60 \text { and } 90 \text { DAS), leaf area, number of pods per plant and hundred seed weight. High } \\
\text { heritability with moderate genetic advance as per cent of mean was recorded for plant } \\
\text { height ( } 90 \text { DAS), days to } 50 \% \text { flowering, days to maturity, pod length and pod width. The } \\
\text { characters like number of branches ( } 30 \text { DAS), chlorophyll content and number of seeds per } \\
\text { pod recorded moderate heritability coupled with low genetic advance over mean. The } \\
\text { studies indicates that the selection may be worthwhile in fenugreek for characters plant } \\
\text { height ( } 30 \text { and } 60 \text { DAS), number of branches per plant ( } 60 \text { and } 90 \text { DAS), number of leaves } \\
\text { (30, } 60 \text { and } 90 \text { DAS), number of pods per plant and hundred seed weight for achieving } \\
\text { higher yields. }\end{array}$} \\
\hline Keywords & \\
\hline & \\
\hline $\begin{array}{l}\text { Heritability, Genetic } \\
\text { advance, Trigonella } \\
\text { foenum-graecum. }\end{array}$ & \\
\hline Article Info & \\
\hline $\begin{array}{l}\text { Accepted: } \\
28 \text { September } 2017\end{array}$ & \\
\hline & \\
\hline & \\
\hline
\end{tabular}

\section{Introduction}

Fenugreek (Trigonella foenum-graecum L.) is an important seed spice, belonging to the family Fabaceae. It is a native of South Eastern Europe and West Asia and is extensively grown in India, Argentina, Bulgaria, Egypt, France, Morocco, Spain, Turkey, China, Pakistan and Lebanon. In India, fenugreek is grown in about 93,090 ha with an annual production of about $1,12,845$ tonnes. Major producing states are Rajasthan, Madhya Pradesh, Gujarat, Uttar Pradesh and Tamil Nadu. During 2012-2013, India earned about Rs. 10,488 lakhs foreign exchange by exporting 29,622 tonnes of fenugreek (Anon., 2014).

Fenugreek is self-pollinated crop with chromosome number of $2 n=16$. Fenugreek is 
a multipurpose crop being used as a spice, leafy vegetables, fodder and as a medicinal plant. The fresh tender leaves and shoots are much used as a vegetable for human consumption since ancient times and as forage for cattle and also in medicine. The seeds are used in colilc flatulence, dysentery, diarrhoea, dyspepsia with loss of appetite, chronic cough, dropsy and diabetes. Fenugreek seeds are known to lower blood glucose and blood cholesterol levels, because they have large amounts of soluble fibre in them. Fenugreek seeds contain substantial amount of steroidal substance "diosgenin" which is used as a starting material in the synthesis of sex hormones and oral contraceptives. It is also important for animals, ground fine powder is mixed with cotton seed and fed to cows to increase the flow of milk.

Yield being a complex character, is influenced by a number of yield contributing characters controlled by polygenes and also influenced by environment. So, the variability in the collections for these characters is the sum total of heredity effects of concerned genes and the influence of the environment. Hence, it becomes necessary to partition the observed variability into heritable and nonheritable components measured as genotypic and phenotypic coefficients of variation (GCV and PCV), heritability and genetic advance expressed as per cent mean. Very little information is available in this direction on fenugreek. Keeping this in view, an attempt was made in the present investigation to assess the magnitude of variability, heritability and genetic advance for different characters in fenugreek germplasm.

\section{Materials and Methods}

The present investigation was undertaken during rabi 2014-15 at Spice Unit, Main Agricultural Research Station, University of
Agricultural Sciences, Dharwad. The experimental material comprised of 35 diverse genotypes from different research stations and local collections and the genotype Gujarat Methi 2 was sown as check. The experiment was laid out in Randomized Complete Block Design with two replications. The plot size was of $2 \times 1 \mathrm{~m}$ with row to row spacing of $30 \mathrm{~cm}$ and plant to plant spacing of $10 \mathrm{~cm}$. All recommended agronomic practices and plant protection measures were followed timely for successful raising the crop. The data on days to $50 \%$ flowering and days to maturity was recorded on plot basis, while, five plants were tagged at random to record data on important growth and yield contributing characters, which were analyzed by the standard statistical methods.

Phenotypic and genotypic coefficients of variation were estimated according to (Burton and Devane, 1953). Heritability in broad sense was estimated by (Hanson et al., 1956). The extent of genetic advance and genetic advance as percentage over mean were worked out using the formula suggested by (Robinson, 1965).

\section{Results and Discussion}

The values of mean, range, phenotypic coefficient of variation (PCV), genotypic coefficient of variation (GCV), heritability, genetic advance and genetic advance expressed as per cent mean for all the characters studied are presented in Table 1 and Figures 1 and 2.

Phenotypic coefficient of variation ranged from $6.06 \%$ (pod width) to $34.07 \%$ (number of leaves at 90 DAS). Genotypic coefficient of variation ranged from $3.45 \%$ (chlorophyll content) to $32.48 \%$ (number of leaves at 90 DAS). The phenotypic co-efficient of variation (PCV) was higher than genotypic co-efficient of variation $(\mathrm{GCV})$ for all the 
characters except leaf area under study indicating the influence of G X E on most of the characters. Higher values of phenotypic and genotypic coefficient of variations were observed for the characters like plant height at 30 DAS, number of branches (60 and 90 DAS), number of leaves at 90 DAS and hundred seed weight. (Bhojanagouda, 2011; Abhishek, 2012) for plant height; for number of branches by (Datta et al., 2005; Abhishek, 2012; Singh et al., 2012; Prajapati et al., 2010), for 100 seed weight by (McCormick et al., 2009; Singh and Pramila, 2009; Bhojanagouda, 2011). The result indicates presence of very high degree of variability and better scope for improvement.

Moderate GCV and high PCV were observed for characters like plant height at 60 DAS, number of leaves (30 and 60 DAS), number of pods per plant and seed yield per plant. The results indicate the existence of comparatively high variability which could be exploited for improvement through selection in advanced generation. Similar observations were made by (Sarada et al., 2008; Bhojanagouda, 2011; Abhishek, 2012; Singh et al., 2012) for number of pods per plant and seed yield per plant.

Moderate PCV and GCV were observed for the characters like plant height at 90 DAS, number of branches (30 DAS), leaf area and seed yield per hectare. These observations are in confirmation with (Bhojanagouda, 2011) for seed yield per plant. The characters viz., chlorophyll content, days to $50 \%$ flowering, days to maturity, pod length, pod width and number of seeds per pod showed lower values of PCV and GCV. Similar kind of results were obtained by (Kailashchandra et al., 2000; Verma and Ali, 2012; Kumari et al., 2015 ) for days to $50 \%$ flowering; for days to maturity by (Kumari et al., 2015) and for pod length by (Sarada et al., 2008; Verma and Ali, 2012), for number of seeds per pod by
(Kailashchandra et al., 2000; Kumari et al., 2015). This suggests presence of narrow genetic base for these traits. Improvement in these characters can be brought about by hybridization or induced variability to widen genetic base and then selecting in segregating generations.

Low differences between PCV and GCV for all traits except herbage yield per plant, herbage yield per sq. m. and dry matter per plant. Low differences between PCV and GCV indicating that they are less affected by environment and comparatively stable. Thus phenotypic selection would be effective in the improvement of these characters.

The characters viz., herbage yield per plant, herbage yield per sq.m. and dry matter per plant recorded moderate to high $\mathrm{PCV}$ and GCV values with wide range, indicating more influence of environment on these characters, making them less amenable for improvement through selection.

The estimates of heritability ranged from 21.59 per cent (number of branches at 30 DAS) to 97.70 per cent (Days to maturity). The heritability was found to be higher for the characters namely plant height (30, 60 and 90 DAS), number of branches (60 and 90 DAS), number of leaves $(30,60$ and 90 DAS), leaf area, days to $50 \%$ flowering, days to maturity, number of pods per plant, pod length, pod width and hundred seed weight. Similar observations were made by (Sarada $e t$ al., 2008; Bhojanagouda, 2011; Abhishek, 2012) for plant height; for number of branches by (Prajapati et al., 2010; Abhishek, 2012; Jain et al., 2013); for days to $50 \%$ flowering by (Ahari et al., 2010; Kole and Saha, 2013); for number of pods per plant by (Singh and Pramila, 2009; Verma and Ali, 2012); for hundred seed weight by (Singh and Pramila, 2009; Ahari et al., 2010; Verma and Ali, 2012; Kole and Saha, 2013). 
Table.1 Variability, heritability and genetic advance in fenugreek genotypes

\begin{tabular}{|c|c|c|c|c|c|c|c|c|}
\hline $\begin{array}{l}\text { Sl. } \\
\text { No. }\end{array}$ & Characters & Range & Mean & $\begin{array}{c}\text { GCV } \\
(\%)\end{array}$ & $\begin{array}{c}\text { PCV } \\
(\%)\end{array}$ & Heritability (\%) & $\begin{array}{l}\text { Genetic } \\
\text { advance }\end{array}$ & $\begin{array}{c}\text { Genetic } \\
\text { advance } \\
\text { over mean } \\
(\%)\end{array}$ \\
\hline 1 & Plant height at $30 \mathrm{DAS}(\mathrm{cm})$ & $1.80-22.90$ & 16.43 & 22.78 & 23.99 & 90.16 & 7.32 & 44.56 \\
\hline 2 & Plant height at 60 DAS $(\mathrm{cm})$ & $24.40-76.30$ & 57.12 & 19.16 & 20.02 & 91.61 & 21.58 & 37.79 \\
\hline 3 & Plant height at $90 \mathrm{DAS}(\mathrm{cm})$ & $45.20-88.60$ & 71.73 & 9.84 & 12.28 & 64.17 & 11.68 & 16.24 \\
\hline 4 & Number of branches at 30 DAS & $2.30-4.20$ & 3.29 & 7.66 & 16.48 & 21.59 & 0.24 & 7.33 \\
\hline 5 & Number of branches at 60 DAS & $4.80-14.70$ & 9.13 & 25.34 & 28.28 & 80.27 & 4.27 & 46.76 \\
\hline 6 & Number of branches at 90 DAS & $7.25-15.90$ & 10.50 & 21.07 & 25.43 & 68.42 & 3.76 & 35.84 \\
\hline 7 & Number of leaves at 30 DAS & $12.60-24.50$ & 18.81 & 17.45 & 20.23 & 74.41 & 5.90 & 31.01 \\
\hline 8 & Number of leaves at $60 \mathrm{DAS}$ & $53.30-104.90$ & 76.50 & 15.77 & 20.36 & 60.01 & 19.26 & 25.17 \\
\hline 9 & Number of leaves at $90 \mathrm{DAS}$ & $23.95-94.33$ & 38.43 & 32.48 & 34.07 & 90.88 & 24.12 & 63.79 \\
\hline 10 & Leaf area $\left(\mathrm{cm}^{2}\right)$ & $5.23-9.24$ & 7.38 & 12.70 & 12.94 & 87.00 & 1.71 & 23.20 \\
\hline 11 & $\begin{array}{l}\text { Chlorophyll content (SPAD } \\
\text { units) }\end{array}$ & $46.75-60.91$ & 55.14 & 3.45 & 6.29 & 30.04 & 2.15 & 3.89 \\
\hline 12 & Herbage yield per plant (g) & $9.57-21.83$ & 16.67 & 11.30 & 20.36 & 30.80 & 2.15 & 12.92 \\
\hline 13 & Herbage yield per sq.m. (kg) & $0.33-0.76$ & 0.58 & 11.87 & 22.15 & 28.72 & 0.08 & 13.10 \\
\hline 14 & Dry matter content(g/plant) & $1.23-5.16$ & 3.30 & 17.77 & 31.27 & 32.32 & 0.69 & 20.81 \\
\hline 15 & Days to $50 \%$ flowering & $35.50-56.00$ & 42.01 & 8.45 & 9.31 & 82.38 & 6.64 & 15.80 \\
\hline 16 & Days to maturity & $76.50-109.00$ & 85.33 & 7.43 & 7.34 & 97.70 & 12.76 & 14.95 \\
\hline 17 & Number of pods per plant & $21.40-55.30$ & 39.38 & 17.46 & 23.48 & 55.27 & 10.53 & 26.74 \\
\hline 18 & Pod length $(\mathrm{cm})$ & 8.03-11.48 & 10.29 & 6.49 & 7.94 & 66.73 & 1.12 & 10.92 \\
\hline 19 & Pod width (mm) & $3.18-4.06$ & 3.59 & 5.48 & 6.06 & 81.54 & 0.37 & 10.19 \\
\hline 20 & Number of seeds per pod & $12.48-16.18$ & 14.50 & 4.03 & 6.44 & 39.19 & 0.75 & 5.20 \\
\hline 21 & Hundred seed weight (g) & $1.03-2.55$ & 1.70 & 20.60 & 28.12 & 53.65 & 0.53 & 31.08 \\
\hline 22 & Yield per plant (g) & $3.35-9.65$ & 6.78 & 17.46 & 24.85 & 49.39 & 1.70 & 25.28 \\
\hline 23 & Yield per hectare (q) & $20.15-35.78$ & 29.20 & 10.35 & 15.03 & 47.36 & 85.66 & 14.67 \\
\hline
\end{tabular}


Int.J.Curr.Microbiol.App.Sci (2017) 6(11): 4020-4036

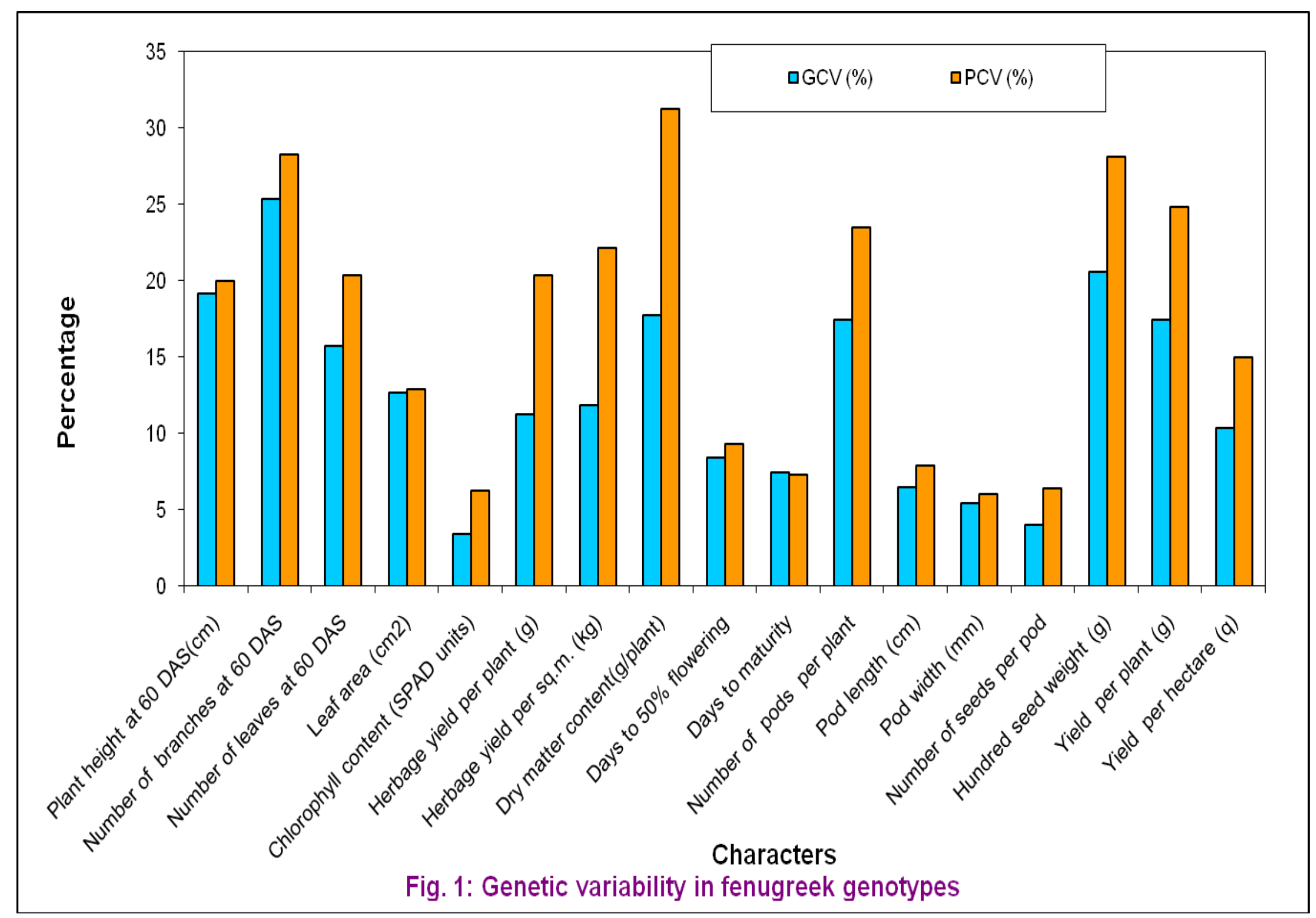




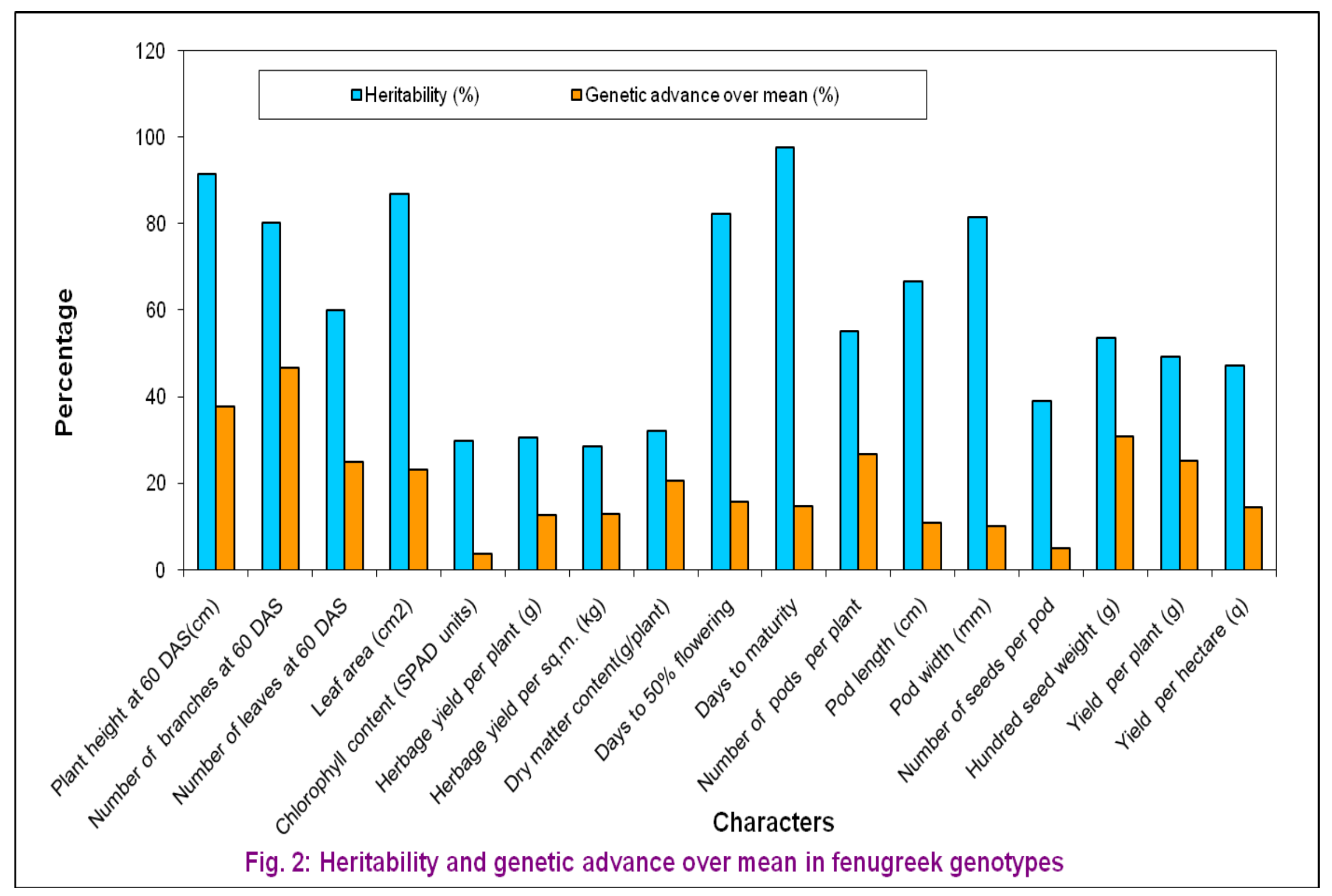


Heritability estimates in broad sense when used in conjunction with the genetic advance would give better information than the heritability alone. In the present study, high heritability coupled with the high genetic advance as per cent mean were noted for plant height (30 and 60 DAS), number of branches (60 and 90 DAS), number of leaves $(30,60$ and 90 DAS), leaf area, number of pods per plant and hundred seed weight suggesting the role of additive gene action in the expression of these characters and as such could be considered as the reliable indices for improvement through selection. These findings are also supported by the results of (Sarada et al., 2008; Bhojanagouda, 2011; Abhishek 2012) for plant height; for number of branches by (Datta et al., 2005; Prajapati et al., 2010; Abhishek 2012; Jain et al., 2013), for number of pods per plant by (Prajapati et al., 2010; Abhishek 2012; Verma and Ali, 2012; Kumari et al., 2015) for hundred seed weight by (Bhojanagouda, 2011; Verma and Ali, 2012; Jain et al., 2013). High heritability with moderate genetic advance as per cent of mean was recorded for plant height (90 DAS), days to $50 \%$ flowering, days to maturity, pod length and pod width. Similar results were obtained by (Balai et al., 2006; Prajapati et al., 2010) for plant height; for days to maturity by (Prajapati et al., 2010). The results indicate that these characters were less influenced by environment but governed by additive and non-additive gene action.

The characters like number of branches (30 DAS), chlorophyll content and number of seeds per pod recorded moderate heritability coupled with low genetic advance over mean. This was the indicative of dominant and epistatic effects for these characters.

Thus, there is influence of environment for these characters. Similar reports were also given by (Balai et al., 2006; Jain et al., 2013) for number of seeds per pod.
From present investigation, high genotypic coefficient of variability and phenotypic coefficient of variability coupled with high heritability coupled with genetic advance as per cent mean were observed for the characters plant height (30 and 60 DAS), number of branches per plant (60 and 90 DAS), number of leaves (30, 60 and 90 DAS), number of pods per plant and hundred seed weight. This indicates that there is a lesser influence of environment in the expression of characters which are amenable for selection.

\section{References}

Abhishek, N., 2012. Characterization of fenugreek (Trigonella foenum-graecum L.) genotypes through morphological characters. Int. J. Agric. Env. Biotech., 5(4): 453-457.

Ahari, S. D., Hassandokht, M. R., Kashi, A. K., Amri, A. and Alizadeh, K. H., 2010. Genetic variability of some agronomic traits in the Iranian fenugreek landraces under drought stress and non-stress conditions. Afr. J. Plant Sci., 4(2): 1220.

Anonymous, 2014. Indian Horticulture Database. www.nhb.gov.in

Balai, O. P., Singh, D. and Jain, U. K., 2006. Genetic variation and character association among yield and yield related traits in fenugreek. Indian J. Agric. Res., 40(2): 143-146.

Bhojanagouda, P., 2011. Evaluation of fenugreek genotypes under northern transitional belt of Karnataka. M. Sc. (Agri.) Thesis, Univ. Agric. Sci., Dharwad, Karnataka (India).

Burton, C. W. and Devane, R. W., 1953. Estimating heritability in tall fescue from replicated clonal material. Agron. J., 4: 78-81.

Datta, S., Chatterjee, R. and Mukherjee, S., 2005. Variability, heritability and path analysis studies in fenugreek. Indian J. 
Hort., 62 (1): 96-98.

Hanson, G. H., Robinson, H. F. and Comstock, R. E., 1956. Biometrical studies of yield in segregating populations of Korean Lespedeza. Agron. J., 48: 267-282.

Jain, A., Singh, B., Solanki, R. K., Saxena, S. N. and Kakani, R. K., 2013. Genetic variability and character association in fenugreek (Trigonella foenum-graecum L.). Int. J. Seed Spices, 3(2): 22-28.

Kailashchandra, E. V., Divakar, S. and Singh, D. L., 2000. Genetic variation and character association of seed yield and its component characters in fenugreek. Agril. Sci. Digest, 20(2): 93-95.

Kole, P. C. and Saha, A., 2013. Studies on variability and heritability for different quantitative characters in fenugreek under different environments. J. Plant Breed. Crop Sci., 5(11): 224-228.

Kumari, J., Kulkarni, G. U. and Sharma, L. K., 2015. Studies on genetic variability, correlation and path analysis in fenugreek (Trigonella foenum-graecum L.). Frontiers in Crop Improvement J., 3(1): 46-48.

McCormick, K. M., Norton, R. M. and Eagles, H. A., 2009. Phenotypic variation within a fenugreek (Trigonella foenum-graecum L.) germplasm collection. II. Cultivar selection based on traits associated with seed yield.
Genet. Resour. Crop Evol., 56: 651661.

Prajapati, D. B., Ravindrababu, Y. and Prajapati, B. H., 2010. Genetic variability and character association in fenugreek (Trigonella foenum-graecum L.). J. Spices Aromatic Crops, 19(2): 61-64.

Robinson, H. F., 1965. Quantitative genetics in relation to breeding on conterminal of mendalism. Indian J. Genet., 26(4): 191-197.

Sarada, C., Giridhar, K. and Hariprasada, R. N., 2008. Studies on genetic variability, heritability and genetic advance in fenugreek. J. Spices Aromatic Crops, 17(2): 163-166.

Singh, K. P., Jain, P. K., Sengupta, S. K., Mehta, A. K. and Nair, B., 2012. Variability, heritability and genetic advance in fenugreek germplasms. JNKVV Res. J., 46(3) 328-332.

Singh, S. P. and Pramila, 2009. Genetic variability, heritability and genetic advance for quantitative characters in fenugreek (Trigonella foenum-graecum Linn). Asian J. Hort., 4(1): 167-169.

Verma, P. and Ali, M., 2012. Genetic variability in fenugreek (Trigonella foenum-graecum L.) assessed in South Eastern Rajasthan. Int. J. Seed Spices, 2(1): 56-58.

\section{How to cite this article:}

Jyothi Veerayya Hosamath, R.V. Hegde, C.K. Venugopal, A.G. Vijayakumar and Hegde, M.G. 2017. Studies on Genetic Variability, Heritability and Genetic Advance in Fenugreek (Trigonella foenum-graecum L.). Int.J.Curr.Microbiol.App.Sci. 6(11): 4020-4036. doi: https://doi.org/10.20546/ijcmas.2017.611.471 